\title{
The genus Sesuvium (Aizoaceae, Sesuvioideae) in the Southern Cone
}

\author{
Carlos R. Minué1,* (i) \& Adriel I. Jocou' ${ }^{1}$ (i)
}

Key words: Aizoaceae, lectotypification, new synonyms, revision, South America, taxonomy, Trianthema.

Ključne besede: Aizoaceae, lektotipifikacija, novi sinonimi, revizija, Južna Amerika, taksonomija, Trianthema.
Received: 7. 9. 2020

Revision received: 2. 1. 2021

Accepted: 7. 1. 2021

\begin{abstract}
Sesuvium is a genus of 14 to 17 species of succulent plants, both annual and perennial, widely distributed in tropical and subtropical regions. The genus Sesuvium has not yet been studied in detail in the Southern Cone (Argentina, Southern Brazil, Chile, Paraguay and Uruguay), which has led to a misidentification of numerous specimens as $S$. portulacastrum. As part of the ongoing floristic, taxonomic and ecologic studies in Argentina, we revise the genus Sesuvium for the Southern Cone. This study is based on field investigation, examination of herbarium specimens, and revision of literature. The taxonomic treatments, maps of distribution, detailed descriptions, photographs, an illustration, a dichotomous key and a comparative table to differentiate the species of the genus Sesuvium occurring in the Southern Cone are presented. Finally, ecological, morphological, and taxonomic aspects of the species are discussed. The new combination of $S$. americanum (三 Trianthema americanum Gillies ex Arn.; = S. verrucosum Raf.) is proposed. Lectotypes for three names are here designated ( $S$. revolutifolium Vahl ex Willd.; S. revolutifolium Lam., and S. parviflorum DC.). Four species should be accepted for the Southern Cone: S. americanum, S. humifusum, S. mezianum and S. sessile. Furthermore, $S$. portulacastrum is excluded from the flora of the Southern Cone.
Izvleček
V rod Sesuvium uvrščamo od 14 do 17 vrst sukulentnih rastlin, enoletnic in trajnic s široko razširjenostjo v tropskih in subtropskih območjih. Rod Sesuvium in Urugvaj) še ni bil podrobneje raziskan in posledica so bile številne napačne določitve osebkov kot $S$. portulacastrum. Med florističnmi, taksonomskimi in ekološkimi raziskavami v Argentini smo naredili revizijo rodu Sesuvium za južni podrobni opis, fotografije, ilustracije, dihotomni ključ in primerjalno tabelo za razlikovanje vrst rodu Sesuvium, ki se pojavljajo v južnem delu Južne Amerike. Razpravljali smo o ekoloških, morfoloških in taksonomskih vidikih teh vrst. $\mathrm{Za}$ S. americanum (三 Trianthema americanum Gillies ex Arn.; = S. verrucosum Raf.) smo predlagali novo kombinacijo. Predlagali smo tri lektotipe za tri imena (S. revolutifolium Vahl ex Willd.; S. revolutifolium Lam. in S. parviflorum DC.).
Za preučevano območje so veljavne štiri vrste: $S$. americanum, S. humifusum, S. mezianum in S. sessile. Vrsto $S$. portulacastrum pa moramo izločiti iz flore južnega dela Južne Amerike v območju južnega dela Južne Amerike (Argentina, južna Brazilija, Čile, Paragvaj del Južne Amerike. V študiji smo opravili terenske raziskave, pregledali herbarijske primerke in literaturo. Predstavili smo taksonomsko obdelavo, karte razširjenosti,
\end{abstract}

1 Departamento de Biología Aplicada, Facultad de Ciencias Agrarias, Universidad Nacional del Comahue, RN N 151 km 12,5, Casilla de Correo 85, 8303 Cinco Saltos, Río Negro, Argentina. E-mail: carlosminue@hotmail.com, adrieljocou@gmail.com

* Corresponding author 


\section{Introduction}

Sesuvium L. (Aizoaceae Martinov., Sesuvioideae Lindl.) is a genus of 14 species of succulent plants, both annual and perennial, widely distributed in tropical and subtropical regions and with a centre of origin in Southern Africa (Bohley et al. 2017, Hartmann 2017, Sukhorukov et al. 2018). Recent studies suggest that at least 17 species should be accepted (Sukhorukov et al. 2018).

The genus Sesuvium has not yet been studied in detail in the Southern Cone (Argentina, Southern Brazil, Chile, Paraguay and Uruguay), which has led to a misidentification of numerous specimens as $S$. portulacastrum (L.) L. Zuloaga et al. (2019) cited two species of Sesuvium for the Southern Cone area: S. portulacastrum and S. humifusum (Turpin) Bohley \& G. Kadereit. However, Bohley et al. (2017) reported additionally S. mezianum (K. Müll.) Bohley \& G. Kadereit (restricted to Paraguay) and S. verrucosum Raf. (a single specimen from 1983 in Argentina).

As part of the ongoing floristic and taxonomic studies of Aizoaceae (see e.g., Jocou et al. 2019a, Jocou \& Minué 2020, Jocou et al. 2020a) and floristic and ecological studies in Argentina (see e.g., Jocou \& Gandullo 2018, 2019, 2020, Minué \& Gandullo 2019, Jocou et al. 2019b, 2020b, Jocou \& Brignone 2020, Minué et al. 2021), we revised the genus Sesuvium for the Southern Cone.

The taxonomic treatments, maps of distribution, detailed descriptions of two species, photographs, an illustration, a dichotomous key and a comparative table to differentiate the species of the genus Sesuvium occurring in the Southern Cone are presented. Finally, ecological, morphological, and taxonomic aspects of the species are discussed.

\section{Materials and methods}

Field investigations were performed in Patagonia (Argentina) for collection of specimens of Sesuvium in the Gran Bajo del Gualicho and Pellegrini Lake (Río Negro province) during 2018 to 2020. All the specimens collected were deposited in ARC. The morphological study of the specimens was performed under stereoscopic microscope Leica EZ4 HD, and the photographs were taken using LAS EZ 3.4.0.

High-quality digital images of Sesuvium specimens collected in the Southern Cone from B, BRIT, CONC, E, F, G, L, MA, NY, P, TEX, U, UCR, US, and UTC (acronyms according to Thiers 2020 [continuously updated]) were examined.

Descriptions, protologues and relevant literature were studied for the typification of names. Protologues and high-quality images of type specimens of Cypselea humi- fusa Turpin, C. meziana K. Müll., S. parviflorum DC., S. revolutifolium Vahl ex Willd., S. revolutum Pers., S. revolutifolium Lam., S. revolutifolium Ortega, S. sessile Pers., S. verrucosum and Trianthema americana Gillies ex Arn., were studied.

Specific literature about Sesuvium and regional floras from the Southern Cone were consulted for study of taxonomic treatments.

A comparative table of morphological features and a dichotomous key were made between the species occurring in the Southern Cone. Distribution maps of the species in the Southern Cone were made. Field and stereoscopic microscope photographs of Sesuvium americanum and S. sessile were taken to complement the descriptions.

The Articles cited throughout the text follow the International Code of Nomenclature for algae, fungi, and plants (ICN; Turland et al. 2018).

\section{Results and discussion}

The identification of the perennial species of Sesuvium occurring in the Southern Cone has been historically erratic, due to their morphological similarity and the few comprehensive taxonomic studies. The presence of $S$. portulacastrum has been erroneously reported in the Southern Cone. We corroborate the occurrence of a North American taxon [S. americanum (Gilliex ex Arn.) A.I. Jocou \& C.R. Minué, comb. nov. $=S$. verrucosum $]$ and a South American taxon $[S$. sessile Pers., $=S$. parviflorum $]$. The latter was synonymised under $S$. portulacastrum (see e.g., Bohley et al. 2017, Brignone 2020) although it presents distinctive features that justify the reinstation to species rank, agreeing with the conclusions of Sukhorukov et al. 2018 for $S$. parviflorum.

The detachment of the aril near of the cotyledon area (Figures 4G, H \& I) represents a taxonomic character (see e.g., Sukhorukov et al. 2018) that allows differentiating some of the species occurring in the Southern Cone. The length of the pedicel would allow differentiating Sesuvium portulacastrum ( $>7 \mathrm{~mm}$ long, sensu Sukhorukov et al. 2018) from other species in the Southern Cone (usually $<2.5 \mathrm{~mm}$ ). Furthermore, the presence and abundance of papillae (bladder cells) (Figures 1A \& B) and warts (Figure 1C) are also useful characters for the identification of species.

The papillae are specialized structures that allow the accumulation of excess salts (Agarie et al. 2007). The density of papillae could be varying to the age of the plant, climatic conditions (Bohley et al. 2017) or even edaphic conditions, such as the concentration of salts. However, the density of papillae and warts appears to be a sufficiently stable feature to differentiate some species. 
To clarify the taxonomy of Sesuvium in the Southern Cone, a dichotomous key, a comparative table (Table 1) and the taxonomic treatment for each species are presented.

\section{Taxonomic treatment}

Sesuvium americanum (Gillies ex Arn.) A.I. Jocou \& C.R. Minué, comb. nov. $\equiv$ Trianthema americanum Gillies ex Arn., Edinburgh J. Nat. Geogr. Sci. 3: 354.1831 Lectotype (designated by Brignone 2020: 13): Argentina, Buenos Aires, "Pampas y Buenos Ayres near Rio del Saladillo", "November to March, 1821", Gillies s.n. (E00621957 digital image!); Isolectotype: E00621958 (digital image!). Figures 2, 3 (C, F \& I) \& 4 (C, F \& I).

= Sesuvium revolutifolium Vahl ex Willd., Enum. Pl. [Willdenow] 1: 521. 1809, nom. illeg. et syn. nov. Lectotype (designated here): Herbarium Willdenow,
"Habitat in America calidiore" (B-W 09667-01 0, digital image!, available in: https://herbarium.bgbm.org/object/ BW09667010).

= Sesuvium verrucosum Raf., New Fl. [Rafinesque] 4: 16. 1836, syn. nov. - Neotype (designated by Bohley et al. 2017: 144): United States of America, Salt River, Arkansas, Nuttall s. n. (P00680440 digital image!, available in: http://coldb.mnhn.fr/catalognumber/mnhn/p/ p00680440); Isoneotype: P00680439 (digital image!) - Epitype (designated by Bohley et al. 2017: 144): United States of America, California, Riverside, San Jacinto Valley, 15-X-1999, Sanders et al. 23186 (BRIT, not seen); Isoepitypes: UCR (digital image!, available in: https://cch2.org/portal/collections/individual/index. php?occid=1481905), UTC00230499 (digital image!, available in: https://intermountainbiota.org/imglib/h_ seinet/intermt/UTC/UTC00230/UTC00230499.jpg), CAS?, DAV?, RSA?, SD?.

Table 1: Comparison table of the features of Sesuvium species in the Southern Cone.

Tabela 1: Primerjalna tabela lastnosti vrst rodu Sesuvium v južnem delu Južne Amerike.

\begin{tabular}{|c|c|c|c|c|}
\hline Features & S. americanum & S. humifusum & S. mezianum & S. sessile \\
\hline Life span & Perennial & Annual & Perennial & Perennial \\
\hline $\begin{array}{l}\text { Papillae } \\
\text { (bladder cells) }\end{array}$ & $\begin{array}{c}\text { Prominent, densely } \\
\text { covered in stem, leaves } \\
\text { and sepals }\end{array}$ & Small, flat & Absent & $\begin{array}{l}\text { Usually absent, if present then not } \\
\text { prominent, loosely and only in the } \\
\text { younger parts }\end{array}$ \\
\hline Leaf, size (mm) & $5-30 \times 4-15$ & $4-12 \times 2-8$ & $5-7 \times 2-3$ & $5-40 \times 4-15$ \\
\hline Leaf, blade & Flat, often revolute & Flat & Flat & Flat, usually revolute \\
\hline Leaf, insertion & Shortly petiolate & Petiolate & Shortly petiolate & Shortly petiolate \\
\hline Leaf, shape & $\begin{array}{c}\text { Linear, spatulate, obovoid, } \\
\text { oblong or linear-oblong }\end{array}$ & $\begin{array}{c}\text { Elliptic to } \\
\text { ovate }\end{array}$ & $\begin{array}{c}\text { Obovate to } \\
\text { oblanceolate }\end{array}$ & $\begin{array}{c}\text { Linear, spatulate, oblong or } \\
\text { linear-oblong }\end{array}$ \\
\hline Leaf, apex & Obtuse, often retuse & $\begin{array}{l}\text { Obtuse to } \\
\text { acute }\end{array}$ & $\begin{array}{c}\text { Obtuse to } \\
\text { rounded }\end{array}$ & Obtuse, often slightly retuse \\
\hline Leaf, base & $\begin{array}{l}\text { Attenuate to narrowly } \\
\text { cuneate }\end{array}$ & Obtuse & $\begin{array}{l}\text { Obtuse to } \\
\text { attenuate }\end{array}$ & Attenuate to narrowly cuneate \\
\hline Pseudostipules, margin & Entire & Fimbriate & Entire & Entire \\
\hline Flower, length $(\mathrm{mm})$ & $5-8$ & $3-4$ & $3-5$ & $5-10$ \\
\hline Pedicel, length (mm) & $0-2$ & $3-4$ & $1-3$ & $0-2.5$ \\
\hline Stamens, number & Numerous & 3 & 3 & Numerous \\
\hline Carpels, number & $3-5$ & $2(-3)$ & 3 & $3-5$ \\
\hline Styles, number & $3-5$ & $2(-3)$ & $3 ?$ & $3-5$ \\
\hline Aril and seed coat & $\begin{array}{l}\text { Small detachment near the } \\
\text { cotyledon area, with hardly } \\
\text { noticeable pits }\end{array}$ & $\begin{array}{l}\text { Covers the } \\
\text { seed, entire, } \\
\text { reticulated }\end{array}$ & Not seen & $\begin{array}{l}\text { Very noticeable detachment } \\
\text { near the cotyledon area }\end{array}$ \\
\hline Seed, length $(\mathrm{mm})$ & $0.8-0.9$ & ca. 0.2 & Not seen & $0.8-0.9$ \\
\hline Seed, shape & Rounded-reniform & $\begin{array}{l}\text { Rounded } \\
\text { reniform }\end{array}$ & Not seen & Rounded-reniform \\
\hline Seed, colour & $\begin{array}{l}\text { Lustrous, slightly } \\
\text { iridescent, black }\end{array}$ & $\begin{array}{l}\text { Glossy, light- } \\
\text { brown }\end{array}$ & Not seen & $\begin{array}{l}\text { Lustrous, slightly iridescent, } \\
\text { black }\end{array}$ \\
\hline
\end{tabular}


Description: - Succulent perennial herb, sometimes suffruticose toward the base. Stem procumbent to erect, usually many branched and leaved, densely papillate, usually with few warts. Leaves fleshy, opposite, blade green to greyish-green, usually ashy brown or greyish when dry, linear, spatulate, obovoid, oblong or linear-oblong, flat, often revolute, 5-30 × 4-15 mm, slightly verrucose, densely papillate, margin entire, apex obtuse, often retuse, base attenuate to narrowly cuneate; petioles $1-3 \mathrm{~mm}$ long, densely papillate, pseudostipules hyaline, without papillae, clasping the stem, margin entire. Floral bracts in one pair at the base of pedicels, without papillae, triangular to lanceolate, often with margin slightly toothed, $1-1.2 \times 0.5-0.7 \mathrm{~mm}$. Flowers solitary in axils, sessile to subsessile, 5-8 $\mathrm{mm}$ long, ovoid to slightly turbinate when closed; pedicels $0-2 \mathrm{~mm}$ long, densely papillate. Sepals 5 , green outside, white, pale pink, pink, violet, purplereddish inside, fused at the base, lobes erect, imbricate, cucullate, ovate to ovate-lanceolate, unequal, the 3 broad

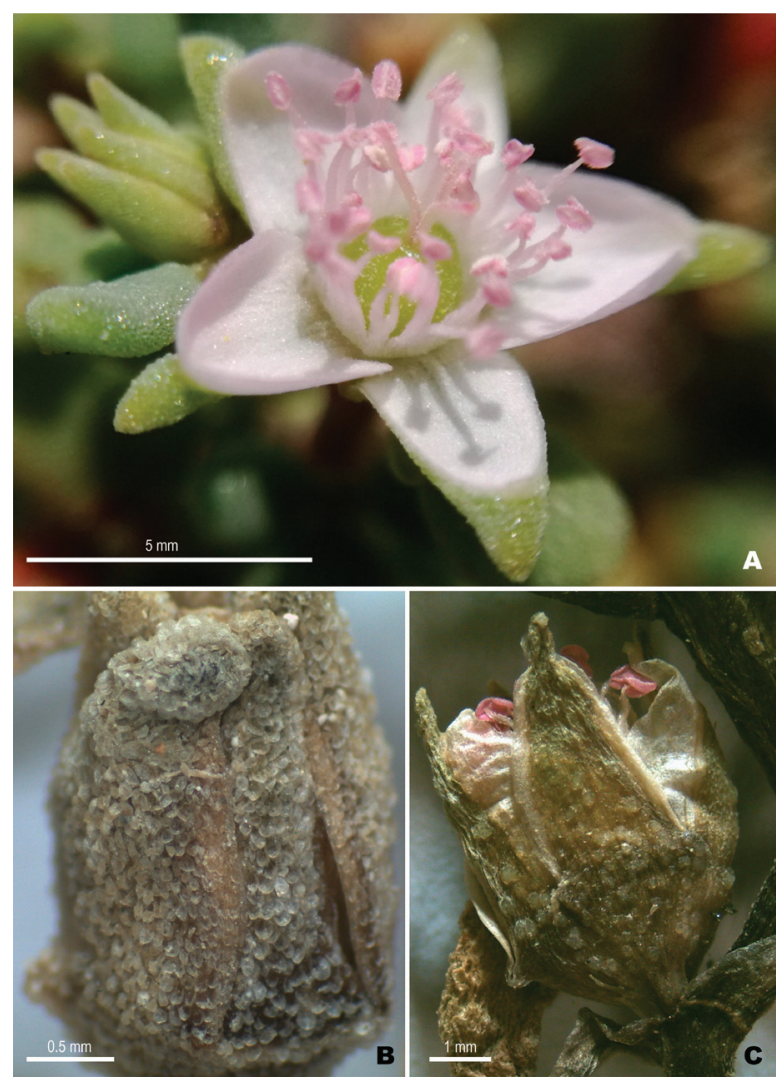

Figure 1: Features of Sesuvium americanum (A, B) and S. sessile (C). A: close-up of flower and leaves in fresh (Minué \& Jocou s.n.). B: close-up of papillae in the sepals (Minué \& Jocou s.n.). C: close-up of warts in the sepals (Jocou \& Minué 2381).

Slika 1: Lastnosti vrst Sesuvium americanum (A, B) in S. sessile (C). A: bližnji pogled cveta in listov (Minué \& Jocou s.n.). B: bližnji pogled papil na čašnih listih (Minué \& Jocou s.n.). C: bližnji pogled bradavic na čašnih listih (Jocou \& Minué 2381). ones ca. $5 \times 4 \mathrm{~mm}$, the 2 narrow ones ca. $5 \times 2.5 \mathrm{~mm}$; margins hyaline without warts or papillae, dorsal surface slightly verrucose, densely papillate; subapical dorsal mucro obvious, ca. $1 \mathrm{~mm}$ long. Stamens numerous; filaments fused at base, ca. $3 \mathrm{~mm}$ long; anthers pink, often white, ca. $0.7 \mathrm{~mm}$ long. Ovary globose, glabrous; carpels 3-5; styles 3-5, free, 3-4 mm long. Capsules, globose to ovoid, $3-6 \times 2.5-3.5 \mathrm{~mm}$, circumscissile in the lower fourth of the fruit, locules 3-5. Seeds numerous, rounded-reniform, black, lustrous, slightly iridescent, hardly noticeable pits, $0.8-0.9 \times 0.6-0.7 \mathrm{~mm}$; aril with small detachment near the cotyledon area.

Illustrations: - Ocampo Acosta (2002: 4); Fadaie et al. (2006: 89, Figure 1).

Notes: - Sesuvium americanum was mentioned for Argentina for the first time by Bohley et al. (2017, as S. verrucosum) referring to a single collection.

Taxonomic notes: - Numerous specimens of Sesuvium americanum from Argentina have been incorrectly identified as $S$. portulacastrum. However, S. portulacastrum lacks of the dense papillate indument and the detachment of the aril in the cotyledon area, and bears flowers with pedicels more than $7 \mathrm{~mm}$ long.

Nomenclatural notes: - Arnott (1831) proposed the name Trianthema americanum (as "americana") based on specimens of Gillies, giving a diagnosis in Latin, the provenance of the specimens ("НАв. Near Laguna del Arbolito on the west side of Rio Saladillo, forming the western limit of the Pampas") and the date of collection ("November to March, 1821").

Although many authors have proposed Trianthema americanum as synonym (or possible) of Sesuvium portulacastrum (see e.g. Hauman 1925, Bohley et al. 2017, Zuloaga et al. 2019) or S. sessile (see e.g. Hartmann 2017) we studied the lectotype (and isolectotype) kept at $\mathrm{E}$ that matches the features of $S$. verrucosum (particularly ovoid and sessile-subsessile flowers, and dense papillae indumentum) (Figure 2). Consequently, as $T$. americanum has nomenclatural priority against $S$. verrucosum we propose here the new combination of S. americanum.

The name Sesuvium revolutifolium, validly published by Willdenow (1809) and ascribed to Vahl, is an illegitimate name because it is a later homonym of $S$. revolutifolium published by Ortega (1797). We have found two sheets corresponding to original materials of $S$. revolutifolium at Willdenow's herbarium (B-W). The B-W specimens are considered as part of the original material of $S$. revolutifolium, published by Willdenow in his Enumeratio plantarum, partly on the basis of the statements of the "Praefatio" (Willdenow 1809: V) (see e.g., Jocou et al. 2020a). However, this is only a guide, indicating that Willdenow 


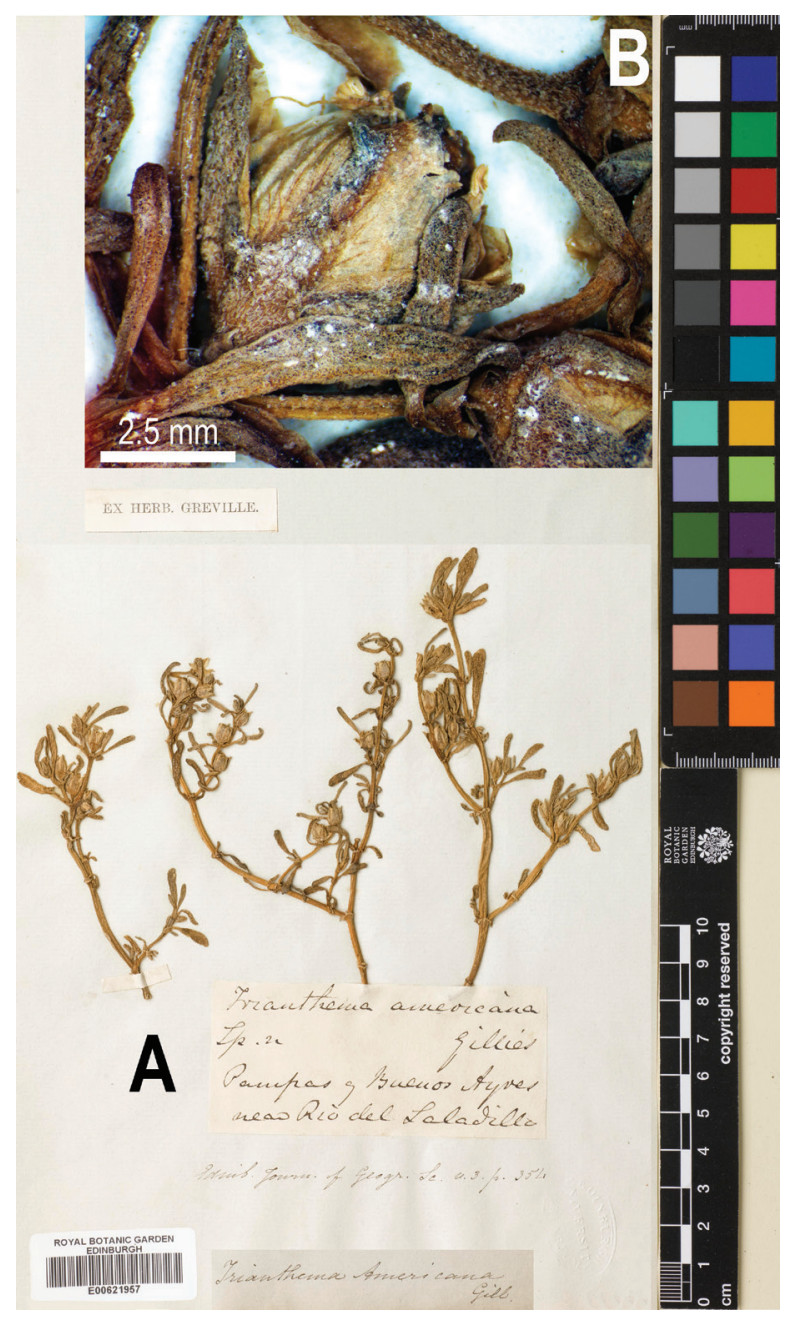

Figure 2: Lectotype of Trianthema americanum (E00621957). A: general view of the sheet. B: close-up under stereoscopic microscope. Images provided by herbarium E (Royal Botanic Garden Edinburgh). Reproduced with permission.

Slika 2: Lektotip vrste Trianthema americanum (E00621957). A: splošni pogled herbarijske pole. B: bližnji pogled z stereomikroskopom. Slike je omogočil herbarij E (Kraljevi botanični vrt Edinburgh). Natis z dovoljenjem.

saw at least one specimen from his herbarium, but not necessarily any particular specimen extant in B-W. Since the sheets of the specimens shows handwriting by Willdenow, there is no reason to doubt that these specimens are original material for the name as reported by various authors (e.g., Iamonico 2020, Jocou et al. 2020a). Since Willdenow (1809) did not indicate the holotype and the existence of two sheets, theses specimens are syntypes and a lectotypification is necessary (Arts. 9.3 and 9.6 of ICN). The study of these syntypes suggests that they correspond to the species treated here as $S$. americanum, mainly due to the presence of a dense papillate indument. We designate here as lectotype the sheet B-W 09667-01 0 since its good state of preservation and quantity of material. The syntype that correspond to the sheet B-W 09667020 (available in: https://herbarium.bgbm.org/object/ BW09667000) cannot be considered as an isolectotype since it is probably not from the same gathering.

Distribution, habitat and ecology: — Sesuvium americanum is native to North America (although perhaps it could be native in South America) and behaves as a pioneer and invasive species of saline environments (Chapman 1960, Ungar 1966, 1968, Ocampo Acosta 2002, Hartmann 2017). Sesuvium americanum inhabits coastal wetlands and salty-gypseous soils, as well as dunes and soils with high clay content and alkaline pH (Ungar 1968, Ferren 2003, Flores-Olvera et al. 2016). This species is a weed of irrigated soils and garbage dumps in Socotra and the Arabian Peninsula (Miller 1996). Sesuvium americanum is naturalized on several continents: America (Cuba, Peru), Asia (Saudi Arabia, Bahrain, United Arab Emirates, Iran, Syria, Vietnam), Africa (Macaronesian region) (Abbas \& El-Oqlah 1992, Fadaie et al. 2006, Al-Eisawi \& Al-Ruzayza 2015, Bohley et al. 2017, Sukhorukov et al. 2018). In this sense, the presence of exotic species with these characteristics generates negative ecological consequences on the original biodiversity of saline environments (Capdevila-Argüelles et al. 2013).

The distribution of Sesuvium americanum in the Southern Cone according to the specimens examined is shown in Figure 5A. This species grows mainly in inland environments, in saline rivers banks, and edges of saline lagoons, lakes and bowls.

In Argentina, Sesuvium americanum is present in the provinces of Buenos Aires (e.g., Las Mulas Lagoon and Epecuen Lake), Córdoba, La Pampa, La Rioja, Mendoza, Río Negro (e.g., Gran Bajo del Gualicho), San Juan, and San Luis (e.g., Río Desaguadero). The Las Mulas Lagoon (Chascomús, Buenos Aires province) is a flat landscape with swampy soil surrounding it, hydromorphic with alkaline inclusions, and a silty texture (Debelis et al. 2005). The vegetation of the area according to Debelis et al. (2005) and the original label of the specimen Zimmerman 2156 (Typha L. sp., Heliotropium L. sp., Distichlis spicata (L.) Greene, and D. laxiflora Hack.), and the physicochemical data of the lagoon water (Colautti, pers. comm.) demonstrate the salinity of the area (Ragonese \& Covas 1947, Cantero et al. 1996, Fernández et al. 2018, Gandullo et al. 2019, Minué et al. 2021). The Gran Bajo del Gualicho (Río Negro province), is located in an area where the relief and climate determine halomorphic soils (Marchionni et al. 1998, Brodtkorb 1999, Alonso 2006, Panza et al. 2008) with a typical native halophilic flora [e.g., Salicornia neei Lag., Heterostachys ritteriana (Moq.) Ung.-Sternb., Allenrolfea vaginata (Griseb.) Kuntze, 
Atriplex undulata (Moq.) D. Dietr., and Pappophorum philippianum Parodi] in silty-sandy soils (authors results, following methodology of Yolcubal et al. 2004). The Mosmota area, near the Desaguadero River (San Luis province) is characterized by soils with good drainage, sandy-loam textures, moderately saline, with calcium carbonate (Peña Zubiate \& d'Hiriart 2006).

In Chile, Sesuvium americanum grows at least in the Arica province (I Región) and Isla Sala y Gómez (V Región). We found specimens collected in Presidente Hayes department (Paraguay), including a record from Salada Lagoon. Further studies are necessary for establish the real distribution of the species in these two countries.

The data reveal the plasticity of Sesuvium americanum to inhabit habitats with varying relief, soil textures and salt concentrations; as indicated by its frequent association with saline bodies of water.

The discovery of specimens collected in Argentina, Chile and Paraguay since 1821 to the present, and the biological characteristics of the taxon, confirm that Sesuvium americanum is naturalized according to the criteria of Pyšek et al. (2004). Consequently, this species must be considered part of the flora of the Southern Cone.

Common names and uses: - Some Spanish names are "saladillo", "verdolaga de playa", "romerillo", "siempre viva" and "deditos" (Ocampo Acosta 2002, GonzálezMedina et al. 2009, Granados-Sánchez et al. 2011, Ruiz et al. 2014). In the United States of America and European countries it is called "sea purslane" (Miller et al. 2009).

Sesuvium americanum was introduced to other countries for landscaping and ornamental purposes as well as for erosion control on sand dunes (Schweitzer \& Erell 2014). It has also been used in Mexico to desalinate soils with moderate salt content (Lastiri-Hernández et al. 2019). In Bahrain, it is used for medicinal purposes, specifically for ear ailments (Taha \& Alsayed 2000). In California, both its leaves and seeds are used for human consumption (Fauvelle et al. 2017).

Material examined: - ARGENTINA. Buenos Aires: Adolfo Alsina, lago Epecuen, 12-XI-1943, Cabrera 8048 (F). Chascomús, Chascomús, 17-XII-1983, Zimmerman 2156 (TEX). Monte Hermoso, Monte Hermoso, 1916, Carette s.n. (NY04242090). Villarino, Salinas Chicas, 20XI-1981, Villamil \& Nicora 2195 (NY). S.d., "Pampas y Buenos Ayres, near Río del Saladillo", "November to March, 1821", Gillies s.n. (E00621957, E00621958). Córdoba: San Justo, alrededores de Miramar, 9-II-1964, Hunziker et al. 16911 (NY). La Pampa: Catriló, Uriburu, 23-XII-1944, Fortuna 46(F). Utracán, camino a Gral. Acha sobre médano, 28-XI-1959, Troncoso s.n. (US03611527). La Rioja: Chamical (ex Gobernador Gordillo), Llanos de
La Rioja, Salina La Antigua, El Infiernillo, 21-V-1959, Hunziker et al. 14355 (NY). Mendoza: La Paz, margen derecha del Desaguadero entre $33^{\circ} 10^{\prime}$ y $33^{\circ} 27^{\prime}$ lat. S, 5-III-1944, Semper s.n. (NY04242089). Lavalle, 15-III1940, Dawson 960 (NY). S.d., Gillies s.n. (E00621959). Río Negro: San Antonio, Gran Bajo del Gualicho, cerca de RP N², 08-II-2020, Minué \& Jocou s.n. (ARC). San Juan: San Martín, cerca de laguna, 17-I-1987, Kiesling \& Meglioli 6460 (NY). San Luis: Juan Martín de Pueyrredón, Desaguadero/ Mosmota, III-1911, Gerth s.n. (L1693491). CHILE. Arica y Parinacota (I Región): Arica, $2 \mathrm{~km}$ from the Panamericana towards Caleta Vítor, 20?-III-1997, Eggli et al. 2796 (CONC 138590). Valparaíso (V Región): Isla de Pascua, Isla Sala y Gómez, 6-IX-1995, Retamal s.n. (CONC 131390). PARAGUAY. Presidente Hayes: Río Verde, cerca de Pozo Colorado, 25X-1980, Fernández Casas \& Molero 4501 (G, NY); laguna Salada y alrededores, 27-III-1996, Mereles \& Degen 6254 (G); km 300 s/ruta Trans-Chaco, 3-III-1979, Mereles $1167(\mathrm{G})$.

Sesuvium humifusum (Turpin) Bohley \& G. Kadereit, Syst. Bot. 42(1): 134. 2017. $\equiv$ Cypselea humifusa Turpin, Ann. Mus. Natl. Hist. Nat. 7: 219. 1806 - Lectotype (designated by Bohley et al. 2017: 134): Dominican Republic, XII-1806, P. A. Poiteau s.n. (P01900032 digital image!, available in: http://coldb. $\mathrm{mnhn} . \mathrm{fr} /$ catalognumber/mnhn/p/p01900032); Isolectotype B 101071825 (digital image!).

Description: - For a detailed description see Bohley et al. (2017).

Illustrations: - Bohley et al. (2017: 135, Figure 7); Brignone (2020: 13).

Notes: - Sesuvium humifusum was recorder at the first time for Argentina by Eskuche (1989) and included by Brignone (2020) in the taxonomic treatment of Sesuvium for Flora of Argentina. We were unable to examine the specimens (see material of reference) and more studies are necessary.

Taxonomic notes: - This species is very easy to distinguish of other species of Sesuvium present in the Southern Cone for the life span (annual) and the margins of pseudoestipules (fimbriates).

Distribution, habitat and ecology: - Species native of the Caribbean and introduced in North America (Bohley et al. 2017). Common in alluvial freshwater areas and vernal pools, but not in saline soils (Bohley et al. 2017).

In Argentina occurs in the Corrientes province (Figure 5A), on banks of the Paraná river (Eskuche 1989).

Common names and uses: - "Panal" (Bohley et al. 2017). 
Material of reference: - ARGENTINA. Corrientes: Corrientes Capital, Molina Punta, 17-IX-1970, Skuche 675 (SI); 14-VI-1970, Skuche 1723 (CTES).

Sesuvium mezianum (K. Müll.) Bohley \& G. Kadereit, Syst. Bot. 42(1): 138. 2017. इ Cypselea meziana K. Müll., Bot. Jahrb. Syst. 42 (2-3, Beibl. 97): 72. 1908 - Lectotype (designated by Jocou \& Minué 2020: 69): Paraguay, Asunción, "Plaines bordant le Rio Paraguay, covertes D'efflorescences saleés, á l'Assomption”, X-1875, Balansa 2263 (P04583791 digital image!, available in: http://coldb.mnhn.fr/catalognumber/mnhn/p/ p04583791); Isolectotypes: G00102877 (digital image!), F-V0360256F (digital image!).

Description: - For a description see Müller (1908) and Bohley et al. (2017).

Notes: - Sesuvium mezianum was described for Paraguay by Müller (1908) (see also Bohley et al. 2017). We have only been able to examine images of the type specimens (see Jocou \& Minué 2020). Sesuvium mezianum is a poorly studied species and apparently restricted to Paraguay (Figure 5A). However, there are more distant records that need to be confirmed (Sukhorukov, pers. comm.).

Taxonomic notes: - This species can be distinguish from the other perennial species present in the Southern Cone by the number of stamens ( 3 vs. numerous) and length of the flowers (3-5 $\mathrm{mm} v$ s. more than $5 \mathrm{~mm}$ ).

We consider that Sesuvium mezianum may be conspecific (or at least very closely related) with $S$. microphyllum Willd. since the morphological similarity (mainly in the habit), although $S$. microphyllum has around 30 stamens. Further studies are necessary to delimit and describe detailly both species.

Material examined: - PARAGUAY. Asunción: Plaines bordant le Rio Paraguay, covertes D'efflorescences saleés, á l'Assomption, X-1875, Balansa 2263 (G, P, F).

Sesuvium sessile Pers., Syn. Pl. [Persoon] 2(1): 39. 1807 - Lectotype (designated by Bohley et al. 2017: 139): Illustration in De Candolle (1799), plate 9 (available in: https://www.biodiversitylibrary.org/page/280684) - Epitype (designated by Bohley et al. 2017: 139): Uruguay, Montevideo, Jussieu Collection, Commerson 138 (P00680445 digital image!, available in: http://coldb.mnhn.fr/catalognumber/mnhn/p/p00680445); Isoepitype: P01900029 (digital image!). Figures 3 (A, B, D, E, G \& H), 4 (A, B, $\mathrm{D}, \mathrm{E}, \mathrm{G} \& \mathrm{H}) \& \mathbf{6}$.

= Sesuvium revolutum Pers., Syn. Pl. [Persoon] 2(1): 39 . 1807, syn. nov. - Lectotype (designated by Hartmann 2001: 300): Illustration in De Candolle (1837?, ined?), fig. 179 , not seen.
= Sesuvium revolutifolium Lam., Tabl. Encycl. 2: 545. 1819, nom. illeg. et syn. nov. - Lectotype (designated here): Illustration in Lamarck (1794), pp. 217, pl. 434, fig. 2 (available in: https://www.biodiversitylibrary.org/ page/43516109).

= Sesuvium parviflorum DC., Prodr. [A. P. de Candolle] 3: 453. 1828, syn. nov. - Lectotype (designated here): Uruguay, Montevideo, "Au pied du Morne de Mont Video. le long de la plage", Commerson 138 (P01900029 digital image!, available in: http://coldb.mnhn.fr/catalognumber/mnhn/p/p01900029); Isolectotype: P00680445 (digital image!).

Description: - Succulent perennial herb, suffruticose toward the base. Stem procumbent to erect, many branched and leaved, with many warts, glabrous, papillate only in the younger parts. Leaves fleshy, opposite, blade green to pale green, usually green or dark brown when dry, linear, spatulate, oblong or linearoblong, flat, usually revolute, $5-40 \times 4-15 \mathrm{~mm}$, usually with many warts, without papillae, if presents then loosely and in young ones, margin entire, apex obtuse, often slightly retuse, base attenuate to narrowly cuneate; petioles $2-5 \mathrm{~mm}$ long, verrucose, pseudostipules hyaline, without papillae, clasping the stem, margin entire. Floral bracts in one pair at the base of pedicels, without papillae, triangular to lanceolate, often with margin slightly toothed, $1-1.2 \times 0.5-0.7 \mathrm{~mm}$. Flowers solitary in axils, the terminals sessile to subsessile, the basal often pedicellate, $5-10 \mathrm{~mm}$ long, ovoid to slightly turbinate when closed; pedicels $0-2.5 \mathrm{~mm}$ long, verrucose, usually glabrous. Sepals 5, green outside, white, pale pink, pink, rarely reddish or yellowish inside, fused at the base, lobes erect, imbricate, cucullate, ovate to ovate-lanceolate, unequal, the 3 broad ones ca. $5 \times 4 \mathrm{~mm}$, the 2 narrow ones ca. $5 \times 2.5 \mathrm{~mm}$; margins hyaline without warts or papillae, dorsal surface with many warts, glabrous to loosely papillate; subapical dorsal mucro obvious, ca. $1 \mathrm{~mm}$ long. Stamens numerous; filaments fused at base, ca. $3 \mathrm{~mm}$ long; anthers pink, often white, ca. $0.7 \mathrm{~mm}$ long. Ovary globose, glabrous; carpels 3-5; styles 3-5, free, 3-4 mm long. Capsules globose to ovoid, 3-6 $\times 2.5-$ $3.5 \mathrm{~mm}$, circumscissile in the lower fourth of the fruit, locules 3-5. Seeds numerous, rounded-reniform, black, lustrous, slightly iridescent, $0.8-0.9 \times 0.6-0.7 \mathrm{~mm}$; aril with very noticeable detachment near the cotyledon area.

Notes: - Sesuvium portulacastrum was reported for Chile by Taylor (1992), for Paraguay by Degen \& Mereles (1996) and for Argentina by various regional floras (see e.g. Cabrera 1953, Fabris 1967, Pérez-Moreau 1984, Troncoso 1987, Novara 2012, Brignone 2020). However, the study of specimens from the Southern Cone identi- 

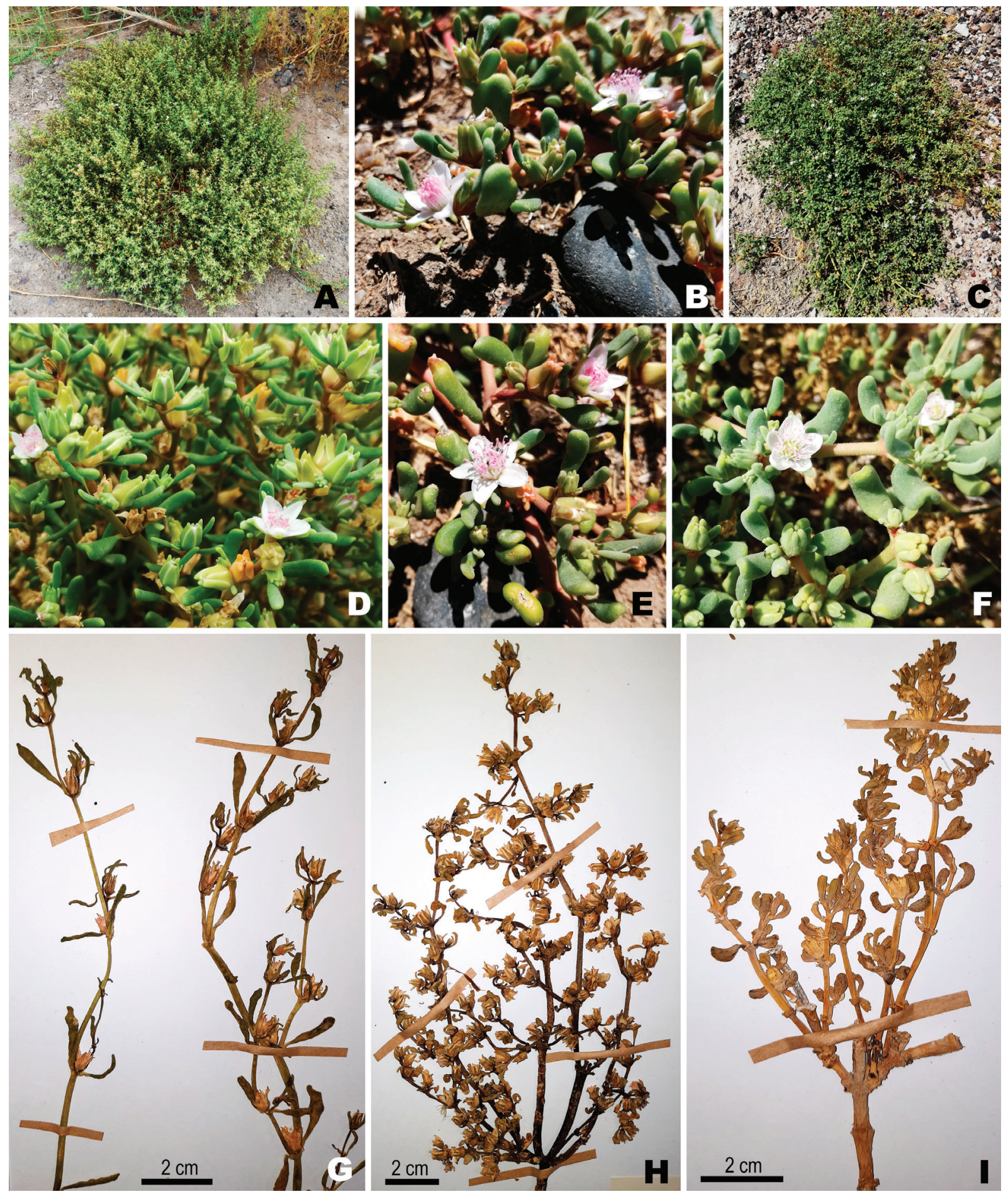

Figure 3: Morphological features of Sesuvium sessile (A, B, D, E, G, H) and S. americanum (C, F, I). A-C: habit. D-F: close-up of flowers and leaves. G-I: herbarium specimens. A, D, G: from Jocou \& Minué 2192; B, E, H: from Jocou \& Minué 2381; C, F, I: from Minué \& Jocou s.n. (ARC).

Slika 3: Morfološke lastnosti vrst Sesuvium sessile (A, B, D, E, G, H) in S. americanum (C, F, I). A-C: habitus. D-F: bližnji pogled cvetov in listov. G-I: herbarijski primerki. A, D, G: iz Jocou \& Minué 2192; B, E, H: iz Jocou \& Minué 2381; C, F, I: iz Minué \& Jocou s.n. (ARC). 
fied as $S$. portulacastrum, confirmed that these actually correspond to $S$. sessile (and a few to $S$. americanum). Consequently, we suggest excluding $S$. portulacastrum from the flora of the Southern Cone. Sesuvium portulacastrum seems widely distributed in Brazil, but we were unable to examine specimens from Southern Brazil (part of Southern Cone: states of Paraná, Rio Grande do Sul and Santa Catarina) reported by Reitz (1984) for the state of Santa Catarina.
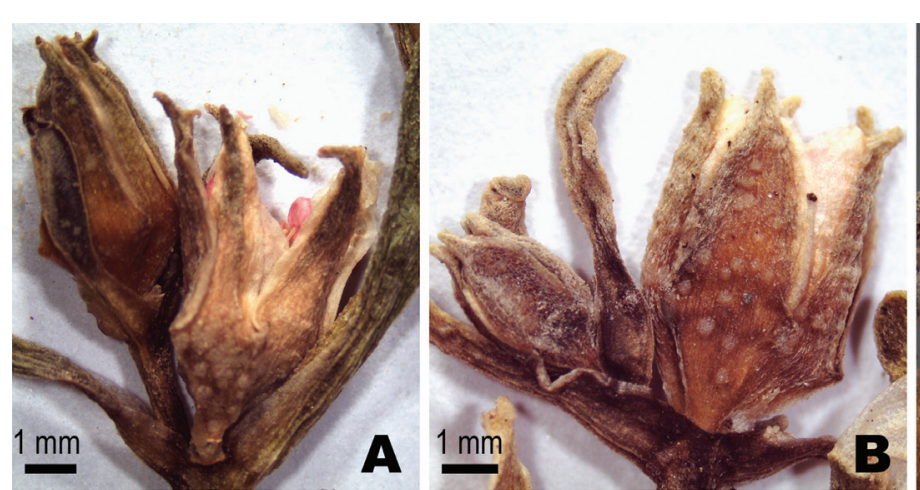

Taxonomic notes: - Sesuvium sessile differs from S. portulacastrum mainly in the remarkable detachment of the aril (Figures 4G, H \& 6F), the usually revolute leaves and the sessile to subsessile flowers ( $v s$. pedicels more than $7 \mathrm{~mm}$ in S. portulacastrum, Sukhorukov et al. 2018). Sesuvium sessile differs from $S$. americanum mainly in the aril (very noticeable detachment vs. small detachment, Figures 4G-I) and the indument (glabrous to loosely papillate $v$ s. densely papillate, Figures $4 \mathrm{~A}-\mathrm{F}$ ).

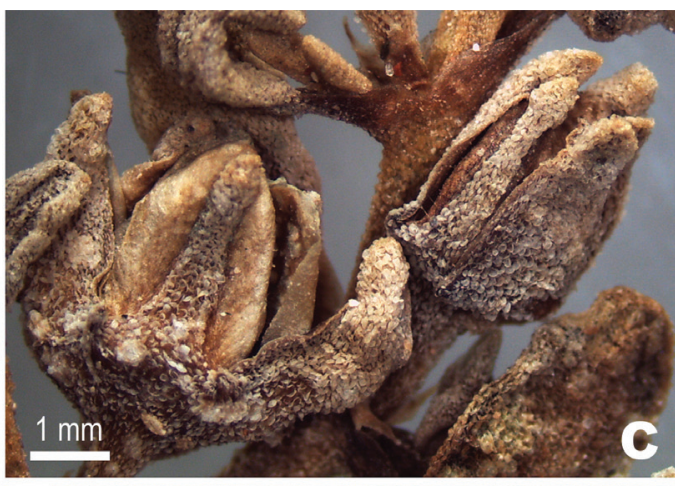

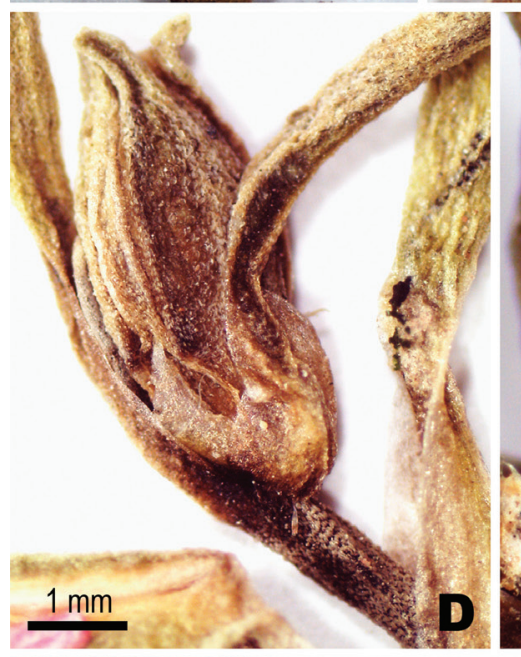
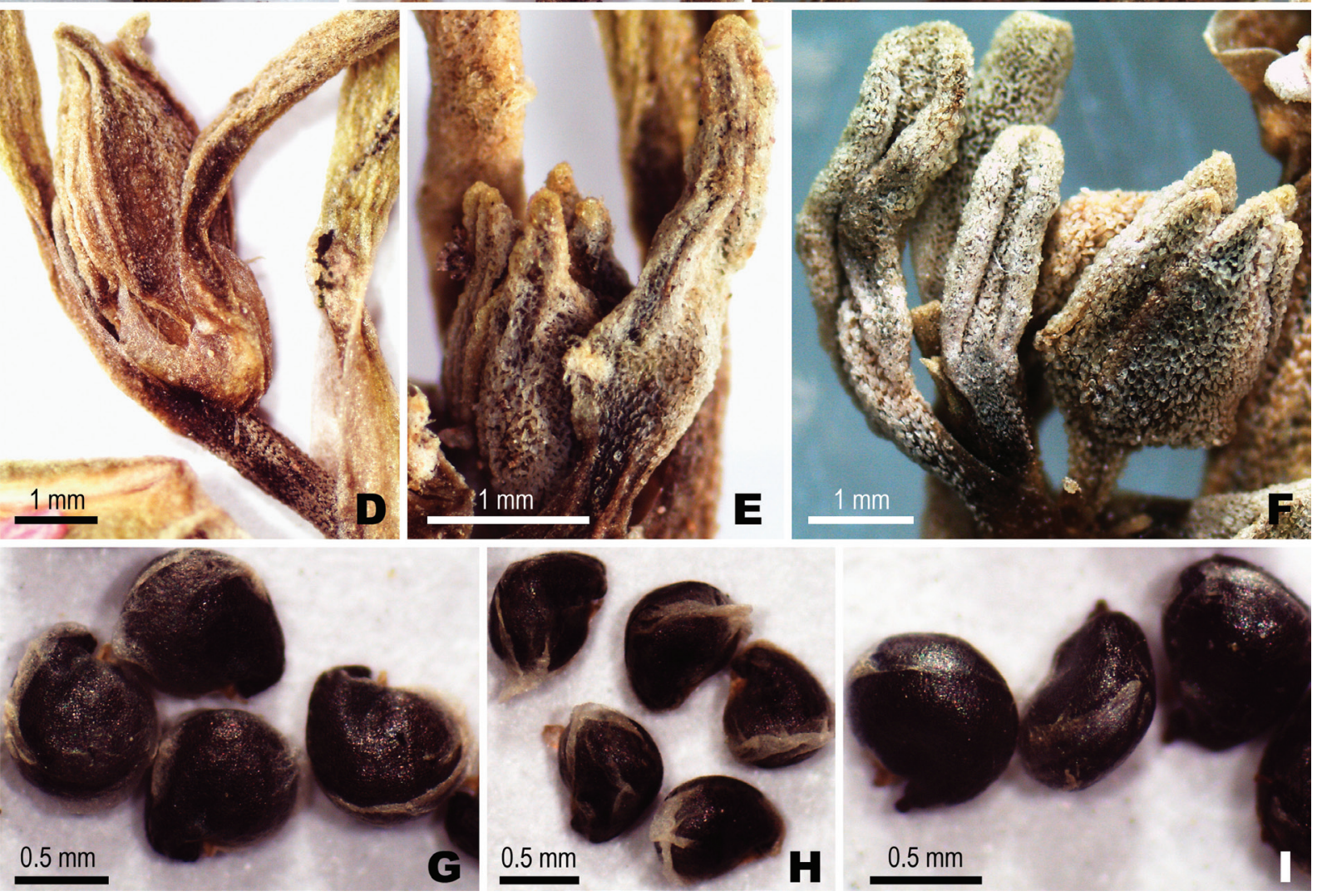

Figure 4: Morphological features of Sesuvium sessile (A, B, D, E, G, H) and S. americanum (C, F, I) under stereoscopic microscope. A-C: density of warts and papillae. D-F: density of papillae. G-I: detachment of the aril. A, D, G: from Jocou \& Minué 2192; B, E, H: from Jocou \& Minué 2381; C, F, I: from Minué \& Jocou s.n. (ARC).

Slika 4: Morfološke lastnosti vrst Sesuvium sessile (A, B, D, E, G, H) in S. americanum (C, F, I) prikazane s stereomikrokopom. A-C: gostota bradavic in papil. D-F: gostota papil. G-I: del arila (ovoja semena). A, D, G: iz Jocou \& Minué 2192; B, E, H: iz Jocou \& Minué 2381; C, F, I: iz Minué \&́ Jocou s.n. (ARC). 
Nomenclatural notes: - While Bohley et al. (2017) indicated the date of publication of the type of Sesuvium sessile as "1807"; actually corresponds to the year 1799 (see Stafleu \& Cowan 1976).

Although Stafleu \& Cowan (1979) stated that the page of Tableau Encylopédique [...] where the name Sesuvium revolutifolium is included was written by Poiret (Tome 2, Volume 5, Part 2), there is no internal evidence in the publication that ascribe the authorship to Poiret, and Lamarck must be indicated as the correct author of the name (Art. 46.8 of ICN). Regarding the date of effective publication, Stafleu \& Cowan (1979) stated that vol. 5 (2) was published in the year 1819 and should be indicated as the correct year (Art. 31.1 of ICN). Although the name $S$. revolutifolium Lam. was validly published in 1819 , it is an illegitimate name as it is a later homonym of the name published by Ortega (1797) and the protologues of both names have exactly the same diagnosis in Latin. Although Lamarck (1819) provided only a brief diagnosis, an illustration was included (in Lamarck 1794, pl. 434, fig. 2) which is the only available original material and is designated here as lectotype. This illustration complete matches with the Southern Cone taxon treated here as $S$. sessile.

Ortega (1797) validly published the name Sesuvium revolutifolium with a detailed description and a diagnosis in Latin. Although this name was described from Cuba, we consider that it could correspond to the species treated here as $S$. sessile since we did not find sufficient evidence to apply this name to $S$. americanum. Ortega (1797) only indicated the presence of tiny papillae on both sides of the leaves, but in $S$. americanum the papillae also cover abundantly the sepals and stems. Furthermore, no original material could be traced for study. Regarding the statements of Sukhorukov et al. (2018) that the habit described by Ortega (1797) completely matches with $S$. americanum $(=S$. verrucosum), we have observed that $S$. sessile can range from erect to notably prostrate habit (Figures 3A \& B). Consequently, further studies are necessary to establish the correct application of the name $S$. revolutifolium Ortega, which is why it was not included in the current taxonomic treatment.

We have found two sheets corresponding to original materials of Sesuvium parviflorum at P. According to the Art. 9.3 and 9.6 of ICN, the two specimens are syntypes and a lectotypification is necessary. Due the good preservation, we here designate the specimen P01900029 as lectotype.

The type specimens of both Sesuvium sessile and S. parviflorum undoubtedly correspond to the taxon historically treated as $S$. portulacastrum in the Southern Cone.
Distribution, habitat and ecology: - Sesuvium sessile is native of South America and the most widely distributed in the Southern Cone (Figure 5B). This species grows in both coast and inland environments with saline and clayey to sandy soils.

In Argentina, Sesuvium sessile is very widely distributed, and occurs in the provinces of Buenos Aires, Chubut, Corrientes, Formosa, Jujuy, Río Negro, Salta, San Juan, Santiago del Estero, and Tucumán; but probably also distributed in Chaco, Córdoba, Entre Ríos, La Rioja, La Pampa, Mendoza, San Luis, and Santa Fe. This species grows in coastal areas, edges of saline lagoons and lakes, and wet saline bowls.

We only examine two specimens from Chile (Arica province) (one of these cited by Taylor 1992, Villagrán et al. 1019 - CONC), consequently furthermore studies are necessary for establish the actually distribution of the species in this country.

In Uruguay, the species occurs in the departments of Canelones, Montevideo, and Rocha; mainly in coastal areas.

In Paraguay, the species grows in Asunción district and departments of Boquerón, Central, Chaco, and Presidente Hayes; mainly in riparian areas and lagoon edges.

Common names and uses: - In Argentina "verdolaga de campo" (Novara 2012). This species is a good indicator of saline soils (Novara 2012).

Material examined: - ARGENTINA. Buenos Aires: Bahía Blanca, Bahía Blanca, Gillies s.n. (E00621960). Baradero, 22-XI-1937, Burkart 8466 (F, NY). Campana. Otamendi, 3-I-1940, Hunziker 34364 (NY). Chascomús, laguna La Adela, 6-IV-1939, Dawson 665 (NY). General Alvarado, playa de Miramar, II-1929, Scala 6 (NY). Tigre, Benavídez, 2-XII-1982, Múlgura \& Cialdella 278 (US). Chubut: Futaleufú, Corcovado, s.d. (F V0314754F). Corrientes: Lavalle, Santa Lucía, Salinas Grandes, 9-XI1978, Schinini \& Ahumada 15932 (F). Mburucuyá, Estancia Santa Teresa, 28-XII-1954, Pedersen 3078 (US). Mercedes, Macrosistema Iberá, nacimiento del río Corriente, 3-XII-1998, Schinini et al. 8252 (MA). Saladas, Paso Naranjito, 25-IV-1979, Pedersen 12464 (L, NY). Formosa: Patiño, Las Lomitas, 11-XII-1984, Schinini \& Pire 24193 (F, G); Nuevo Porteño, VI-1971, Schulz 15391 (G). S.d., Jórgensen 2373 (US). Jujuy: Ledesma, Ruta Nac. 34, Chalicán, 9-XI-1974, Krapovickas et al. 26682 (G). Santa Bárbara, Laguna de la Brea, 22-VI1901, Fries 227 (US). Río Negro: General Roca, Cinco Saltos, lago Pellegrini, cerca de orillas del lago, 15-XII2019, Jocou \& Minué 2381 (ARC); 17-I-2019, Jocou \& Minué 2192 (ARC). S.d., 1838-1842, Wilkes Explor. 

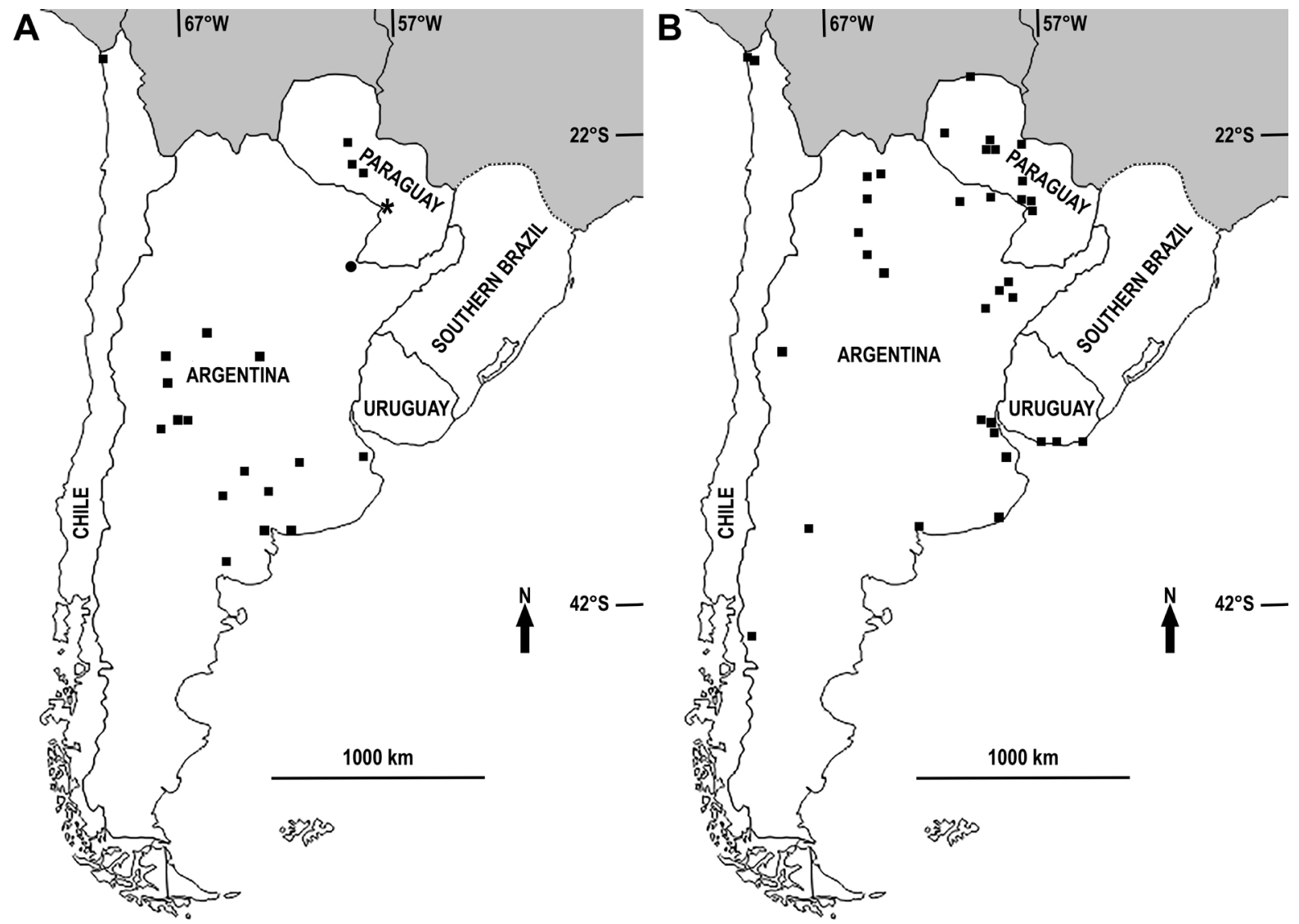

Figure 5: Distribution of Sesuvium in the Southern Cone. A: S. americanum (squares), S. humifusum (circle) and S. mezianum (asterisk). B: S. sessile (squares).

Slika 5: Razširjenost vrst rodu Sesuvium v južnem delu Južne Amerike. A: S. americanum (kvadratki), S. humifusum (krožci) in S. mezianum (zvezdice). B: S. sessile (kvadratki).

Exped., s.d. (US00830094). Salta: General Güemes, Ojo de Agua, Ruta 10, 6-9 km al NE de Gral. Güemes, 12-V-1990, Novara \& Bruno 9875 (G). San Juan: Río de los Patos, Los Hornillos, 9-I-1953, Castellano s.n. (NY04242095). Santiago del Estero: Capital, Capital, 3-IV-1947, Meyer 12027 (NY). Tucumán: Leales, Chañar Pozo, 17-X-1919, Venturi 545 (US). Trancas, Tapia a Vipos, s.d., Schreiter 7371 (U, US). CHILE. Arica y Parinacota (I Región): Arica, Arica, río San José, quebrada junto a la playa, 14-V-1979, Villagrán et al. 1019 (CONC); Arica, 20-V-1917, Skottsberg 1361 (NY). PARAGUAY. Alto Paraguay: Palmar de las Islas, 11-III-1989, Mereles \& Ramella $2852(\mathrm{G})$; Laguna Palmar de las Islas, 28-IV1995, Ramella \& Mereles 2658 (G). Asunción: Asunción, 2-X-1889, Morong 789 (NY). Boquerón: Col. Fernheim, $10 \mathrm{~km}$ E de Campo Grande, 15-IX- 1990, Vanni et al. 2149 (G); Col. Menno, Río Verde, Colonia Lolita, 10IX-1990, Vanni et al. 1867 (G). Central: 1888-1890, Morong 489 (BRY); Lambaré, V-1875, Balansa 2262 (G).
Presidente Hayes: Campo León, Riacho Yacaré Sur, 21III-1996, Mereles \& Degen 6250 (G); Laguna Capitán, 17-X-2004, De Egea et al. 560 (G); Laguna Ganso, 14XII-2010, Vogt 980 (G); Riacho Mosquito, 4-I-2012, Vogt 1315 (G); s.d., Río Pilcomayo, 3-V-1890, Morong 1042 (G, MICH, NY); Río Pilcomayo, "In regione cursus inferioris fluminis Pilcomayo", V-1906, Rojas 49 (G); Santa Elisa, III-1903, Hassler \& Rojas 2821 (G). URUGUAY. Canelones: cerca de la ruta Interbalnearia, ar. Solís chico al E, 23-III-1967, Rosengurtt 10876 (F). Montevideo: Montevideo, Au pied du Morne de Mont Video, le long de la plage, Herbier d'Antoine Laurent de Jussieu, Commerson 138 (P01900029; P00680445); Carrasco, en arenas marítimas, 1934, Legrand 48 (F). Rocha: Paloma, Isla de la Tuna, 6-II-1948, Castellanos s.n. (L1693364). 


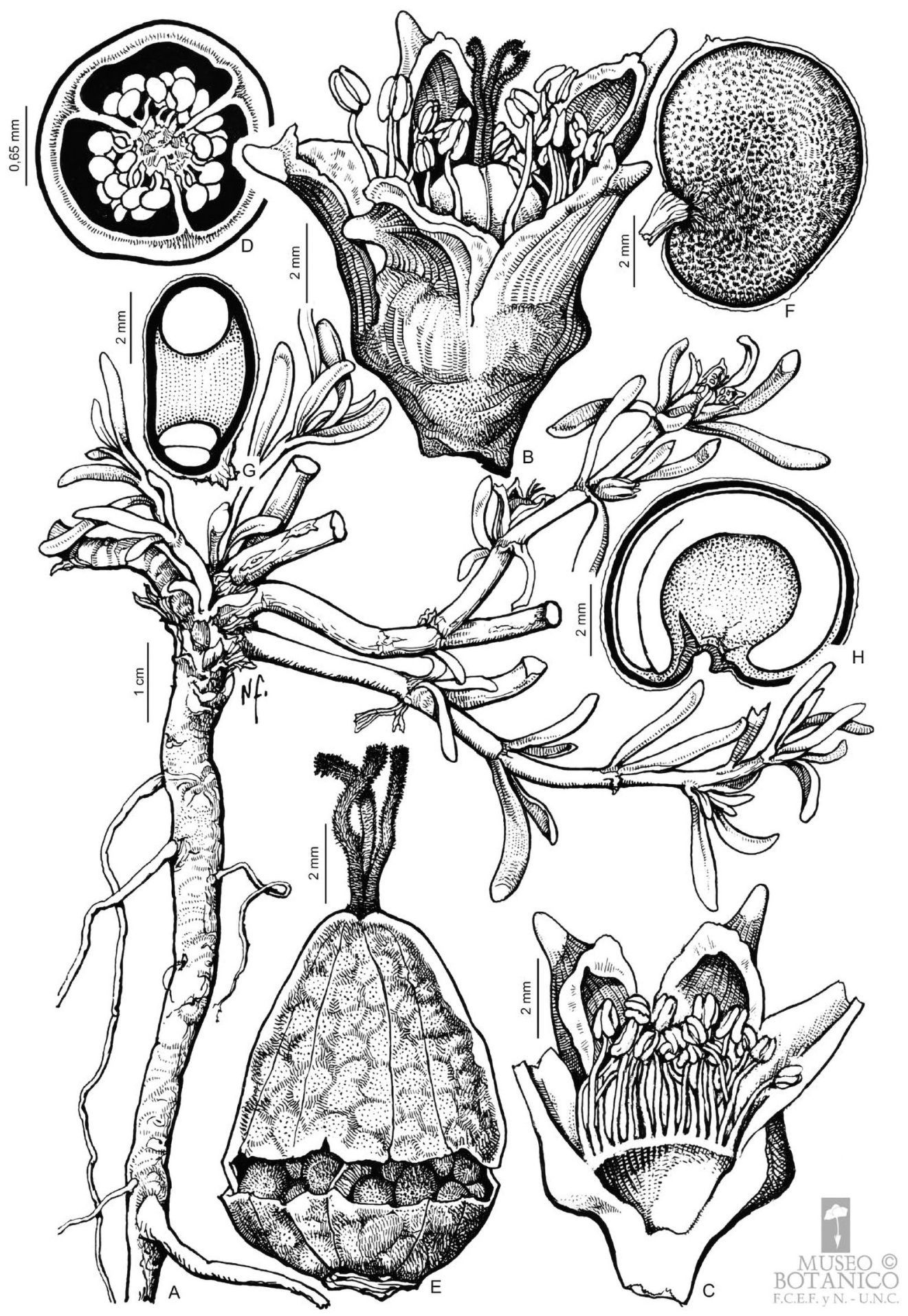

Figure 6: Illustration of Sesuvium sessile. A: habit. B: flower. C: longitudinal section of flower. D: transversal section of ovary. E: capsule. F-H: seed, lateral view, cross and longitudinal section respectively; note the detachment of the aril in F. Illustrated by Nidia Flury from Cocucci 14 (CORD) and A. T. Hunziker 21177 (CORD). Provided by and reproduced with permission of Museo Botánico de Córdoba. 


\section{Excluded taxa from the flora of Southern Cone}

Sesuvium portulacastrum (L.) L., Syst. Nat., ed. 10(2): 1058. 1759. Portulaca portulacastrum L., Sp. Pl. 1: 446. 1753 - Lectotype (designated by Wijnands 1983: 175): Kingdom of the Netherlands, Curaçao, Hermann, Paradisus Batavus seu description rariorum plantarum: 212, icon. 1698!.

This name is excluded from the flora of Southern Cone, because it has been misapplied to specimens of either Sesuvium sessile or $S$. americanum. This species seems to be native of Central America and widely distributed in Brazil, but not in the Southern Cone.

\section{Key for the identification of Sesuvium species occur- ring in the Southern Cone}

1. Annual plants; pseudostipules with fimbriated margins ...................................................... S. humifusum

1'. Perennial plants; pseudostipules with entire margins ..2

2. Stamens 3, flowers 3-5 mm long (Paraguay)..... ..S. mezianum

2'. Stamens numerous, flowers more than $5 \mathrm{~mm}$ long. (widespread) .. 3

3. Papillae usually absent, if present then not prominent, never densely covered and only in young parts; dry material green or dark green, never greyish; aril with very noticeable detachment near the cotyledon area .. S. sessile

3'. Papillae present, prominent, densely covered in leaves, sepals and terminal parts of stems; dry material usually greyish or brown greyish; aril with small detachments near the cotyledon area.

S. americanum

\section{Conclusions}

The morphological study, bibliographic revision and examined specimens, suggest that at least four species (two native and two exotic) should be accepted for the flora of the Southern Cone: Sesuvium americanum, S. humifusum, S. mezianum, and S. sessile. Furthermore, S. portulacastrum is excluded from the flora of the Southern Cone.

The morphological study suggest that features of the aril could be useful to distinguish Sesuvium americanum and $S$. sessile.

Several names of Sesuvium still until without resolve and should be studied for correct application.

Furthermore, studies are necessary to clarify the current distribution of taxa in the Southern Cone.

\section{Acknowledgements}

We thank anonymous reviewers for the suggestions and comments that improved this manuscript. We thank K. Bohley (Jahannes Gutenberg-Universität Mainz), for the photographs provided of the specimen Zimmerman 2156. We thank R. Bijmoer (L), for the information provided, A. Sukhorukov for the comments about Sesuvium, G. Berasain and D. Colautti for the information provided of the Las Mulas Lagoon and R. Gandullo for the assistance during the examination of the ARC herbarium specimens. In addition, we are grateful to A. Marticorena Garri (CONC), R. Drinkwater (E), D. Le (F), C. Niezgoda (F), L. Loze (G), F. Stauffer (G) and A. Weiss (NY) for provide the images of the specimens.

Carlos R. Minué (D) https://orcid.org/0000-0001-9999-4700

Adriel I. Jocou (D) https://orcid.org/0000-0002-8428-8923

\section{References}

Abbas, J. A. \& El-Oqlah, A. A. 1992: Distribution and communities of halophytic plants in Bahrain. Journal of Arid Environments 22(3): 205-218.

DOI: https://doi.org/10.1016/S0140-1963(18)30639-6

Agarie, S., Shimoda, T., Shimizu, Y., Baumann, K., Sunagawa, H., Kondo, A., Ueno, O., Nakahara, T., Nose, A. \& Cushman, J. C. 2007: Salt tolerance, salt accumulation, and ionic homeostasis in an epidermal bladder-cell-less mutant of the common ice plant Mesembryanthemum crystallinum. Journal of Experimental Botany 58(8): 1957-1967.

DOI: https://doi.org/10.1093/jxb/erm057

Al-Eisawi, D. M. \& Al-Ruzayza, S. 2015: The flora of holy Mecca district, Saudi Arabia. International Journal of Biodiversity and Conservation 7(3): 173-189.

DOI: https://doi.org/10.5897/IJBC2014.0773

Alonso, R. N. 2006: Ambientes evaporíticos continentals de Argentina. Serie Correlación Geológica 21(2): 155-170.

Arnott, G. 1831: On some New Species of Portulaceae. The Edinburgh Journal of Natural and Geographical Science 3: 354-356.

Bohley, K., Winter, P. J. \& Kadereit, G. 2017: A revision of Sesuvium (Aizoaceae, Sesuvioideae). Systematic Botany 42(1): 124-147.

DOI: https://doi.org/10.1600/036364417X694575

Brignone, N. F. 2020: Aizoaceae. In: Zuloaga, F. O. \& Belgrano, M. J. (eds.): Flora Argentina, volumen XIX, tomo I. Instituto de Botánica

Darwinion, San Isidro, pp. 5-16.

Brodtkorb, A. 1999: La salina El Gualicho, Río Negro. In: Zappettini, E. (ed.): Recursos Minerales de la República Argentina, volumen I. Instituto de Geología y Recursos Minerales Segemar, Buenos Aires, pp. 1963-1970.

Cabrera, A. L. 1953: Manual de la flora de los alrededores de Buenos Aires. Editorial ACME, Buenos Aires, 589 pp. 
Cantero, J. J., Cantero, A. \& Cisneros, J. M. 1996: Vegetación de los paisajes hidrohalomórficos del centro de Argentina. Universidad Nacional de Río Cuarto, Río Cuarto, 298 pp.

Capdevila-Argüelles, L., Zilletti, B. \& Suárez-Álvarez, V. Á. 2013: Causas de la pérdida de biodiversidad: Especies Exóticas Invasoras. Memorias Real Sociedad Espańola de Historia Natural, 2a. época 10: $55-75$.

Chapman, V. J. 1960: Salt marshes and salt deserts of the world. Interscience Publishers Inc., New York, 392 pp.

De Candolle, A. P. 1799: Plantarum historia succulentarum, vol. 1, an X. Levrault, Paris \& Strasbourg, 49 plates. Available in: https://www. biodiversitylibrary.org/item/9908

DOI: https://doi.org/10.5962/bhl.title.503

Debelis, S. P., Bozzo, A. A., Barrios, M. B. \& Buján, A. 2005: The relationship between soil characteristics and vegetation as a function of landform position in an area of the Flooding Pampa. Spanish Journal of Agricultural Research 3(2): 232-242.

DOI: https://doi.org/10.5424/sjar/2005032-143

Degen, R. \& Mereles, F. 1996: Check-list de las plantas colectadas en el Chaco Boreal, Paraguay. Rojasiana 3: 1-176.

Eskuche, U. G. 1989: Novedades florísticas para el Nordeste Argentino. Folia Botanica et Geobotanica Correntesiana 3: 1-27.

Fabris, H. A. 1967: Aizoaceae. In: Cabrera, A. L. (dir.): Flora de la Provincia de Buenos Aires, Piperáceas a Leguminosas. INTA, Buenos Aires, pp. 171-180.

Fadaie, F., Attar, F. \& Ghahreman, A. 2006: A new record of Aizoaceae (Sesuvium verrucosum Raf.) for the Flora of Iran. The Iranian Journal of Botany 12(1): 87-89.

Fauvelle, M., Esch, E. \& Somerville, A. 2017: Climate change and subsistence exchange in southern California: was western sea-purslane a channel island trade good? American Antiquity 82(1): 183-188. DOI: https://doi.org/10.1017/aaq.2016.3

Fernández, C., Jocou, A. I. \& Gandullo, R. 2018: Vegetación acuática bioindicadora de eutrofización del Alto Valle de Río Negro (Argentina). Ernstia 28(1): 45-93.

Ferren, W. R. 2003: Sesuvium. In: Flora of North America Editorial Committee (eds.): Flora of North America, volume 4. Oxford University Press, United States of America, pp. 80-82. Available in: eFloras.org.

Flores-Olvera, H., Czaja, A., Estrada-Rodríguez, J. L. \& Romero Méndez, U. 2016: Floristic diversity of halophytic plants of Mexico. In: Khan M., Boër B., Özturk M., Clüsener-Godt M., Gul B. \& Breckle S. W. (eds.): Sabkha Ecosystems. Tasks for Vegetation Science, vol 48. Springer, Cham, pp. 299-327.

DOI: https://doi.org/10.1007/978-3-319-27093-7_17

Gandullo, R., Fernández, C. \& Jocou, A. I. 2019: Sintaxonomía de las comunidades de plantas vasculares del sistema de drenaje del Alto Valle de Río Negro, Patagonia, Argentina. Boletín de la Sociedad Argentina de Botánica 54(4): 567-587.

DOI: https://doi.org/10.31055/1851.2372.v54.n4.24826

González-Medina, E., Castillo-Guerrero, J. A. \& Mellink, E. 2009: Relación entre las características de los huevos y del sitio de anidación, con el éxito reproductivo de la Gaviota reidora (Leucophaeus atricilla) en la isla El Rancho, Sinaloa durante la temporada 2007. Ornitología Neotropical 20: 553-564.
Granados-Sánchez, D., Sánchez-González, A., Granados Victorino, R. L. \& Borja de la Rosa, A. 2011: Ecología de la vegetación del desierto chihuahuense. Revista Chapingo, Serie Ciencias Forestales y del Ambiente 17: 111-130.

DOI: https://doi.org/10.5154/r.rchscfa.2010.10.102

Hartmann H. E. K. (ed.). 2001: Illustrated Handbook of Succulent Plants. Aizoaceae F-Z. Springer-Verlag, Berlin, $422 \mathrm{pp}$. DOI: https://doi.org/10.1007/978-3-642-56306-5

Hartmann, H. E. K. 2017: Sesuvium Sesuvioideae. In: Hartmann, H. E. K. (ed.): Aizoaceae. Illustrated Handbook of Succulent Plants. Springer, Berlin, Heidelberg, pp. 1157-1168. DOI: https://doi.org/10.1007/978-3-662-49260-4_128

Hauman, L. 1925: Notes floristiques. Deuxieme série: dicotylédones de l'Argentine. Anales del Museo Nacional de Historia Natural Buenos Aires 32: 395-475.

Iamonico, D. 2020: A nomenclature survey of the genus Amaranthus (Amaranthaceae). 7. Wildenow's names. Willdenowia 50: 147-155. DOI: https://doi.org/10.3372/wi.50.50114

Jocou, A. I. \& Brignone, N. F. 2020: First record of Juncus articulatus subsp. articulatus (Juncaceae) for the Southern Cone Flora. Boletín de la Sociedad Argentina de Botánica 55(4): 631-640. DOI: https://doi.org/10.31055/1851.2372.v55.n4.29938.

Jocou, A. I. \& Gandullo, R. 2018: Primer registro de Epilobium hirsutum (Onagraceae) para la flora Argentina. Darwiniana, nueva serie 6(1): 99-107.

DOI: https://doi.org/10.14522/darwiniana.2018.61.784

Jocou, A. I. \& Gandullo, R. 2019: Sinopsis de las especies de Pyracantha (Rosaceae, Maloideae) naturalizadas en la Argentina. Boletín de la Sociedad Argentina de Botánica 54(4): 599-616. DOI: https://doi.org/10.31055/1851.2372.v54.n4.24970

Jocou, A. I. \& Gandullo, R. 2020: Diversidad de plantas vasculares de los humedales de la Norpatagonia (Argentina). Revista del Museo Argentino de Ciencias Naturales, nueva serie 22(2): 131-154. DOI: https://doi.org/10.22179/REVMACN.22.688

Jocou, A. I. \& Minué, C. R. 2020: Lectotypification of Cypselea meziana (Aizoaceae, Sesuvioideae). Phytotaxa 461(1): 69-71. DOI: https://doi.org/10.11646/phytotaxa.461.1.9

Jocou, A. I., Minué, C. \& Gandullo, R. 2019a: Primer registro de Malephora purpurocrocea (Aizoaceae, Ruschioideae) para la flora Argentina. Darwiniana, nueva serie 7(1): 141-151. DOI: https://doi.org/10.14522/darwiniana.2019.71.821

Jocou, A. I., Minué, C. \& Gandullo, R. 2019b: Matthiola incana (Brassicaceae): primer registro de naturalización en Argentina. Boletín de la Sociedad Argentina de Botánica 54(3): 421-429.

DOI: https://doi.org/10.31055/1851.2372.v54.n3.25366

Jocou, A. I., Minué, C. \& Klak, C. 2020a: Typification and nomenclatural clarifications of Mesembryanthemum purpurocroceum and M. insititium (Ruschioideae, Aizoaceae). Phytotaxa 474(1): 62-70. DOI: https://doi.org/10.11646/phytotaxa.474.1.6

Jocou, A. I., Minué, C. R., Brignone, N. F. \& Gandullo, R. 2020b: Going unnoticed for 40 years: about the presence of the exotic Suaeda paradoxa (Chenopodiaceae, Suaedoideae) in Argentina. Phytotaxa 450(2): 219-228.

DOI: https://doi.org/10.11646/phytotaxa.450.2.7 
Lamarck, J. B. P. A. 1794: Tableau encyclopédique, tome 2, part 1. Panckoucke, Paris, 40 pp. and 100 illustrations. Available in: https:// www.biodiversitylibrary.org/item/141239

DOI: https://doi.org/10.5962/bhl.title.218

Lamarck, J. B. P. A. 1819: Tableau encyclopédique, tome 2, vol. 5, part 2. Panckoucke, Paris, pp. 137-551.

Lastiri-Hernández, M. A., Alvarez-Bernal, D., Bermúdez-Torres, K., Cárdenas, G. C. \& Ceja-Torres, L. F. 2019: Phytodesalination of a moderately saline soil combined with two inorganic amendments. Bragantia 78(4): 579-586.

DOI: https://doi.org/10.1590/1678-4499.20190031

Marchionni, D., Del Blanco, M., de Barrio, R., Romero, S., Schalamuk, I. \& Lombardi, G. 1998: Características texturales y procesos genéticos de los depósitos evaporíticos de la salina del Gualicho, provincia de Río Negro, República Argentina. Revista del Museo de La Plata 11(114): 197-214

Miller, A. G. 1996: Aizoaceae. In: Miller, A. G. \& Cope, T. A.: Flora of the Arabian Peninsula and Socotra vol. 1. Edinburgh University Press, Edinburgh, pp. 155-168.

Miller, M. R., Burns, E. G., Wickland, B. E. \& Eadie, J. M. 2009: Diet and body mass of wintering ducks in adjacent brackish and freshwater habitats. Waterbirds 32(3): 374-387.

DOI: https://doi.org/10.1675/063.032.0302

Minué, C. \& Gandullo, R. 2019: Primer registro de Hibiscus trionum (Malvaceae) para Argentina, en el Alto Valle de Río Negro. Darwiniana, nueva serie 7(1): 167-173.

DOI: https://doi.org/10.14522/darwiniana.2019.71.829

Minué, C. R., Gandullo, R. \& Troncoso, V. Ú. 2021: Diversidad florística de suelos halomórficos cultivados del Alto Valle de Río Negro (Argentina). Caldasia, in press.

Müller, K. 1908: Beiträge zur Systematik der Aizoaceen. Botanische Jahrbücher für Systematik, Pflanzengeschichte und Pflanzengeographie 42(2-3, Beibl. 97): 54-94.

Novara, L. J. 2012: Flora del valle de Lerma - Aizoaceae. Aportes Botánicos de Salta, Ser. Flora 11(2): 1-6.

Ocampo Acosta, G. 2002: Aizoaceae, Fascículo 102. In: Rzedowski, J. \& Calderón de Rzedowski, G. (eds.): Flora del Bajío y de regiones adyacentes. Instituto de Ecología, A. C., Michoacán, Pátzcuaro, pp. 2-6.

Ortega, C. G. 1797: Novarum, aut rariorum plantarum. Ex typographia Ibarriana, Matriti [Madrid], 51 pp., 6 tab.

Panza, J. L. A., Cobos, J. C. \& Cabrera, O. R. 2008: Gran Bajo de San Julián. La depresión más profunda de América. In: Anselmi, G., Ardolino, A., Echevarría, A., Etcheverría, M., Franchi, M., Lagorio, S., Lema, H., Miranda, F. \& Negro, C. (eds.): Sitios de Interés Geológico. Instituto de Geología y Recursos Minerales Segemar, Buenos Aires, pp. 805-813.

Peńa Zubiate, C. A. \& d'Hiriart, A. 2006: Carta de Suelos de la República Argentina, Hoja San Luis, Provincia de San Luis. INTA y Gobierno de la provincia de San Luis, 148 pp.

Pérez-Moreau, R. L. 1984: Aizoaceae. In: Correa, M. N. (dir.): Flora Patagónica, parte 4a, INTA, Buenos Aires, pp. 159-166.

Pyšek, P., Richardson, D. M., Rejmánek, M., Webster, G. L., Williamson, M. \& Kirschner, J. 2004: Alien plants in checklists and floras: towards better communication between taxonomists and ecologists. Taxon 53(1): 131-143.

DOI: https://doi.org/10.2307/4135498

Ragonese, A. E. \& Covas, G. 1947: La flora halófila del sur de la provincia de Santa Fe (República Argentina). Darwiniana 7(3): 401-496.

Reitz, R. 1984: Aizoáceas. In: Reitz, R. (ed.): Flora Ilustrada Catarinense. Herbário Barbosa Rodrigues, Itajaí, pp. 1-9.

Ruiz, J. C. D., Ramírez, R. O. \& Valencia, T. D. J. P. 2014: Recursos florísticos de la cuenca baja del Río Mayo, Sonora. Epistemus 16(8): 36-43.

Schweitzer, O. \& Erell, E. 2014: Evaluation of the energy performance and irrigation requirements of extensive green roofs in a water-scarce Mediterranean climate. Energy and Buildings 68: 25-32.

DOI: https://doi.org/10.1016/j.enbuild.2013.09.012

Stafleu, F.A. \& Cowan, R.S. 1976: Taxonomic Literature. A selective guide to botanical publications and collections with dates, commentaries and types, 2 nd ed., vol. 1. H-Le. Bohn, Scheltema \& Holkema, Utrecht, 1136 pp.

DOI: https://doi.org/10.5962/bhl.title.48631

Stafleu, F.A. \& Cowan, R.S. 1979: Taxonomic Literature. A selective guide to botanical publications and collections with dates, commentaries and types, 2nd ed., vol. 2. H-Le. Bohn, Scheltema \& Holkema, Utrecht, 991 pp.

Sukhorukov, A. P., Nilova, M. V., Erst, A. S., Kushunina, M., Baider, C., Verloove, F., Salas-Pascual, M., Belyaeva, I. V., Krinitsina, A. A., Bruyns, P. V. \& Klak, C. 2018: Diagnostics, taxonomy, nomenclature and distribution of perennial Sesuvium (Aizoaceae) in Africa. PhytoKeys 92: 45-88.

DOI: https://doi.org/10.3897/phytokeys.92.22205

Taha, A. \& Alsayed, H. 2000: Brine Shrimp Bioassay of Ethanol Extracts of Sesuvium verrucosum, Salsola baryosma and Zygophyllum quatarense Medicinal Plants from Bahrain. Phytotherapy Research 14: 48-50. DOI: https://doi.org/10.1002/(SICI) 10991573(200002)14:1<48::AID-PTR536>3.0.CO;2-Z

Taylor, C. M. 1992: Sesuvium portulacastrum y Mesembryanthemum nodiflorum, registros nuevos para la flora de Chile. Gayana, Botánica 49: 11-15.

Thiers, B. (2020 [continuously updated]): Index Herbariorum. A global directory of public herbaria and associated staff. New York Botanical Garden's Virtual Herbarium. Available from: DOI: http://sweetgum.nybg.org/science/ih/ (accessed September 2020).

Troncoso, N. S. 1987: Aizoaceae. In: Troncoso, N. S. \& Bacigalupo, N. M. (eds.): Flora Ilustrada de Entre Ríos, parte 3, INTA, Buenos Aires, pp. 225-230.

Turland, N. J., Wiersema, J. H., Barrie, F. R., Greuter, W., Hawksworth, D. L., Herendeen, P. S., Knapp, S., Kusber, W. H., Li, D. Z., Marhold, K., May, T. W., McNeill, J., Monro, A. M., Prado, J., Price, M. J. \& Smith, G. F. (eds.). 2018: International code of nomenclature for algae, fungi, and plants (Shenzhen Code) adopted by the Nineteenth International Botanical Congress Shenzhen, China, July 2017. Regnum vegetabile 159. Koeltz, Glashütten.

DOI: https://doi.org/10.12705/Code.2018

Ungar, I. A. 1966: Salt tolerance of plants growing in saline areas of Kansas and Oklahoma. Ecology 47(1): 154-155.

DOI: https://doi.org/10.2307/1935756 
Ungar, I. A. 1968: Species-soil relationships on the Great Salt Plains of northern Oklahoma. The American Midland Naturalist 80(2): 392-406.

DOI: https://doi.org/10.2307/2423533

Wijnands, D.O. 1983: The Botany of the Commelins. A. A. Balkema, Rotterdam, 232 pp.

Willdenow, C. L. 1809: Enumeratio plantarum. In Taberna Libraria Scholae Realis, Berolini [Berlin], 1099 pp.

Yolcubal, I., Brusseau, M. L., Artiola, J. F., Wierenga, P. J. \& Wilson, L. G. 2004: Environmental physical properties and processes. In: Artiola, J. F., Pepper, I. L. \& Brusseau, M. L. (eds.): Environmental monitoring and characterization. Elsevier Academic Press, Burlington, pp. 207-239.

DOI: https://doi.org/10.1016/B978-012064477-3/50014-X

Zuloaga, F. O., Belgrano, M. J. \& Zanotti, C. A. 2019: Actualización del Catálogo de las Plantas Vasculares del Cono Sur. Darwiniana, nueva serie 7(2): 208-278

DOI: https://doi.org/10.14522/darwiniana.2019.72.861 